\title{
New Size Measurements in Population Ecology
}

\author{
Manuel Núñez-Nickel \\ José Moyano-Fuentes
}

\begin{abstract}
In organizational ecology, the analysis of the impact of competition between populations on vital ratios is relatively underdeveloped. This paper addresses this issue by developing new competition measurements that focus on the importance of organizational size. The application of these measurements in the case of competition between organizational subforms in a population, and their impact on mortality rates, demonstrate their usefulness for modelling competition. Specifically, the results show how levels of competition between firms in a population can be more clearly analysed when the rival population mass or concentration indices are used.
\end{abstract}

KEY WORDS: competition between subforms, probability of failure, the cross effects of concentration model, the cross effects of density model, the cross effects of mass model

JEL CLASSIFICATION: C41, L11, L25, M29

\section{Introduction}

In organizational ecology, investigations are carried out on how organizational populations change and develop through time by analysing processes of organizational founding, growth,

\author{
Manuel Núñez-Nickel \\ Carlos III University \\ Department of Business Economics \\ C/ Madrid, 126: Despacho 7:32 \\ 28903-Getafe (Madrid) Spain \\ E-mail:mnunez@emp.uc3m.es \\ José Moyano-Fuentes \\ University of Jaén \\ Department of Business Administration \\ C/ Alfonso X el Sabio, 28: Despacho 70201-B \\ 23700-Linares (Jaén) Spain \\ Fax: + 34953026508 \\ Tel: + 34953026571 \\ E-mail: jmoyano@ujaen.es
}

decline, transformation, and mortality. This perspective, in terms of the levels of analysis used, distinguishes between the organizational demography, population ecology, and community ecology of organizations (Hannan and Freeman, 1977, 1989). Organizational demography refers to processes that apply at the level of populations of organizations, population ecology refers to interactions between localized sets of populations, and community ecology refers to the processes that follow from the full set of population interactions in some systems (Carroll and Hannan, 2000).

Although most of the published research in this field is identified as 'ecological', this line of work has a strong demographic element. That is, research on organizational ecology has been fundamentally focused on the first level of analysis. The second level, and particularly the third level, has been relatively unexplored (Astley, 1985; Ranger-Moore et al., 1991; Hunt and Aldrich, 1998; Ingram and Simons, 2000). This limitation is reflected in (1) the limited number of papers developed in both population ecology and community ecology (the second and third levels of analysis) (Carroll and Hannan, 2000), and (2) an almost complete absence of other types of tests because of the systematic application of density, or number of organizations in a population, as the basic variable to represent the size of the populations.

In an effort to extend previous research, this paper: (1) delves deeper into the second level of analysis, population ecology, and puts forward a new test; (2) analyses the effects of competition between two organizational forms, classified in terms of ownership structures, on the probability of survivorship (Barnett and Carroll, 1987; Ranger-Moore et al., 1991; Hannan and Carroll, 1992; Haveman, 1992; Rao and Neilsen, 1992; Barron et al., 1994, 1998); (3) applies new measurements of competition between populations, 
other than that of population density. The objective is to show how alternative measurement protocols enhance our level of understanding of ecology-level dynamics. Thus, we employ new variables that, despite being used in the first level of analysis (population mass and level of concentration), have never been developed within population ecology.

We will test hypotheses using piecewise-exponential models, and we will apply them in the olive oil production industry in the province of Jaén (Spain) during the period 1944-1998. The advantages of using this population are twofold: not only does it belong to a new sector that nobody has previously studied in terms of population ecology, but also, the relevant official sources have provided us with information on the industry's internal characteristics that is considered essential for developing this type of research.

\section{The theoretical background}

\subsection{Models of competition between populations}

The selection can come from either competition between organizations in a given population, or from competition between organizations belonging to different populations (Carroll and Hannan, 1995).

The growth of a population can frequently influence the survival chances of other populations. If two different populations rely on the same set of resources to survive, they will compete between themselves to obtain them. The more these necessary resources coincide for both populations, the greater the level of competition between them. If we define a niche as the set of resources necessary for a population to survive (Hutchinson, 1957), two populations compete if, and only if, their fundamental niches intersect (Hannan and Carroll, 1992, p. 28). We could also say that the greater the overlapping in the fundamental niches, the greater the competition between the populations (Barron et al., 1998, p. 3).

In this way, the bigger the population, the more resources it will consume, and, therefore, the possibility of them being consumed by another population will be reduced, with increasing competition being the result (Rao and
Neilsen, 1992). It is natural, in this perspective, to assume that the intensity of a competitive effect is proportional to the scale (or size) of the competing population. If the first population is of a very small scale, the life chances of the second are not much affected. If the first grows in scale, then competition intensifies. In other words, ecological competition is scale dependent (Barron et al., 1998, p. 13).

Traditionally, population size has been measured by the density or the number of organizations belonging to the population, which has led to the development of the cross effects of density model (Hannan and Freeman, 1989), which establishes that the intensity of competition is proportional to the density of competing populations. This model arises as an extended version of the Lotka-Volterra framework used in biology to likewise register competition between populations. According to this model, two populations compete when the size of each population lowers the carrying capacity of the other, with carrying capacity being defined as the number of organizations that can be sustained in a particular environment in isolation from other populations (Hannan and Carroll, 1992, p. 29). We can express this model mathematically as follows:

$$
\begin{aligned}
& \frac{d n_{1}}{d t}=r_{1} \times n_{1} \times\left[\frac{K_{1}-\alpha_{12} n_{2}-n_{1}}{K_{1}}\right], \\
& \frac{d n_{2}}{d t}=r_{2} \times n_{2} \times\left[\frac{K_{2}-\alpha_{21} n_{1}-n_{2}}{K_{2}}\right] .
\end{aligned}
$$

with $n_{i}$ being the density of population $i$. The growth rate for each population $\left(d n_{i} / d t\right)$ is broken down into three components: (1) $r_{i}$, the intrinsic properties of the form that affect its speed of growth in the absence of resource limitations and competition; (2) $K_{i}$, the carrying capacity of each population; (3) $\alpha_{i j}$, the specific competition between populations (Hannan, 1986, p. 6). Comparing these two equations, we can observe how the presence of the competitor reduces the carrying capacity of the first population from $K_{1}$ to $K_{1}-\alpha_{12} \mathrm{n}_{2}$. The competition coefficients, $\alpha_{12}$ and $\alpha_{21}$, tell how the carrying capacity of each population declines with the density of the competitor $\left(n_{i}\right)$.

The studies that test this model show that interdependencies among populations have a direct 
influence on organizational viability, but not necessarily in the expected direction. We can distinguish three types of interdependence (Hannan, 1986, pp. 3-4; Hannan and Freeman, 1989, pp. 96-97): (1) competitive, (2) predator form, and (3) mutualistic. The first refers to the situation in which the presence of a population reduces the growth rate of another (Baum and Oliver, 1991; Brittain, 1994). In other cases, competitive relationships can change to the predator form when the expansion of a population legitimates the other, but the growth of the second worsens the life chances of the first by eroding its resource base (Swaminathan and Wiedenmayer, 1991; Brittain, 1994). If balanced, coexistence is not possible; the second will invade the first's niche, which will subsequently disappear in accordance with the competitive exclusion principle (Gause, 1934). The relationships will be mutualistic when the expansion of one stimulates the expansion of another, and vice versa, which will reduce their mortality rates (Barnett, 1990; Ingram and Baum, 1997).

In several studies, only one of the cross effects of density is present. The papers developed by Carroll and Wade (1991) and Carroll and Swaminathan (1992) are examples of mutualistic relationships in one direction. In studies by Hannan and Freeman (1988), Barnett (1990), Rao and Neilsen (1992), and Baum, Korn and Kotha (1995) the relationship is competitive.

A final possibility is that interdependence may be nonmonotonic. That is, growth in the density of a population could legitimate another one, until the density growth becomes so great that competitive interactions dominate. We can observe this in Silverman et al. study (1997), whereas the papers by Hannan and Freeman (1989), and Staber (1992) report the opposite result.

All these studies consider that the key variable for estimating the size of a rival population is the number of organizations (or the cross effects of density). It is possible that there are variables other than density that come closer to the concept of population size (Carroll and Harrison, 1994).

In organizational and economic theory, it is believed that larger organizations generate stronger competition than do their smaller rivals because of several factors, such as (1) the ability to reduce their dependence on the environment and other organizations (Thompson, 1967; Pfeffer and Salanzik, 1978), (2) greater market power and superior access to resources (Aldrich and Auster, 1986; Haveman, 1993), (3) greater endurance in situations of resource shortages (Levinthal, 1991), (4) greater recognition (Edwards, 1955), and (5) the securing of benefits derived from economies of scale and scope (Scherer and Ross, 1990).

On the other hand, two factors condition a population's growth rate in a competitive situation with another: the smaller organizations of the rival population proliferating in number, and the organizations in the second population becoming larger in size. We should understand size as a structural feature of the organization, and we measure it as productive capacity or as scale of operations (Barron et al., 1994, pp. 394395). This implies that competition between both populations could be better modelled by using the sum of the sizes of all organizations in the rival population.

Using this global size, we could build a model that examines the competitive interactions produced between populations with similar resource necessities (that is, between populations with overlapping fundamental niches). That is, a model that, like the cross effects density model, uses the Lotka-Volterra framework to discover the effect of the aggregate size of a population on the probability of failure in a second population with which it competes. Using similar terminology, we could call this new model the cross effects of mass model.

To reformulate the Lotka-Volterra model, we have based our work on Barnett and Amburgey's idea (1990). Nevertheless, it would be possible to consider replacing the growth rate in numbers, which we have introduced into the formulae, with the growth rate in mass.

$$
\begin{aligned}
& \frac{d n_{1}}{d t}=r_{1} \times n_{1} \times\left[\frac{K_{m 1}-\gamma_{12} M_{2}-M_{1}}{K_{m 1}}\right], \\
& \frac{d n_{2}}{d t}=r_{2} \times n_{2} \times\left[\frac{K_{m 2}-\gamma_{21} M_{1}-M_{2}}{K_{m 2}}\right] .
\end{aligned}
$$

where $n_{i}$ is the density of population $i, d n_{i} / d t$ represents the growth rate in numbers of the population $i, K_{m i}$ is the mass of the population $i$ that 
can be supported in the niche with the level of resources held constant, and $M i$ is the mass or aggregate size of the population $i$ at a given time.

The presence of a second population in the same niche reduces the mass that can be sustained by this niche regarding the first population from $K_{i 1}$ to $K_{m 1}-\gamma_{12} \mathrm{M}_{2}$. The coefficients $\gamma_{12}$ and $\gamma_{21}$ show how the mass that can be sustained by the niche for each population is reduced with the aggregate size of the competing population.

This model is based on the original Barnett and Amburgey (1990) model, called the mass dependence model, which establishes that the largest organizations are also stronger competitors and, for that reason, global size increases in the population increase death rates. However, from an empirical point of view, the results obtained in studies that incorporate mass in mortality models are not conclusive. Thus, Baum and Mezias (1992) and Hannan and Carroll (1992) find a competitive effect produced by the population mass. Nevertheless, Barnett and Amburgey (1990), Barnett (1997), and Ingram and Baum (1997) find a mutualistic effect of mass on the risk of failure.

Continuing the line of reasoning of this model, the cross effects of the mass model suggest that a population's competitive strength is proportional to its global size, and that this strength is used to obtain the resources needed by its members, thus reducing the life chances of the elements making up the second population that shares the same niche. In short, the increase in the global mass of the largest population should significantly increase the mortality rates in populations with smaller mass.

Ingram and Baum (1997) for the first time introduced the effects that the average mass of a population can have on mortality rates in another population. These authors, however, did not theoretically develop a model that uses cross effects of mass as a key prediction variable for organizational failure. Barron et al. (1998) explicitly introduce competitive interactions in terms of the rival population's mass. The competitive effect of cross effects of mass is introduced into the models to estimate the growth rate of the rival population. Nevertheless, in this research, we use cross effects of mass as a measure that adapts to the concept of competition between populations, affecting the mortality rates of each of them.

The variables used in the cross effects of density models and the cross effects of mass models, even when they are variables that indicate a population's competitive potential, are in themselves incomplete, because, having been measured in absolute values, they do not address the differences existing between members of the same population. That is, the first variable, density, takes into account the number of organizations but not the individual size of each. In contrast, mass takes into account the total volume of the organization but not the number of organizations. If we consider the information given by the mass variable, we cannot discern if a population is composed of an infinite number of organizations of a relative size close to zero, or if it is one single organization that consumes all the resources. To measure both effects at the same time, it is necessary to analyse the size distribution of organizations in a population through concentration (Boone and van Witteloostuijn, 1995). Likewise, to understand the direction of population mass through time, it is necessary to associate it with the many different distributions of organizational sizes that may exist (Barron, 1999, p. 427).

Therefore, if the fundamental niches of two populations intersect, the life chances of the members of one of them depend not only on the level of concentration of its population, but also on the level of concentration of the rival population.

If we consider the internal composition of a population, that is, the differences that exist between the organizations it comprises, it may be possible to understand the competitive dynamics between populations. For this reason, it is vital to incorporate the internal power relationships that are produced between the members of a population, which could be obtained from the relationships between organizational sizes through concentration. To that end, we have built a new model of competitive interactions that uses, as a fundamental exogenous variable, the level of concentration of each population and, to use the same terminology, we call it the cross effects of concentration model. This model extends the Lotka-Volterra framework by introducing competition between populations in 
terms of the level of concentration of each of them.

Given that competition intensity is proportional to the similarity in size of organizations (Hannan and Freeman, 1977; Hannan et al., 1990), a reduced level of concentration would imply strong rivalry between the organizations of the population, because there would be many organizations and the difference in size between them would be reduced. To relieve competitive tension in a population, part of it would be transferred to a neighbouring population. Therefore, it is possible to identify the level of concentration of a population as an indicator of its competitive potential. As the level of concentration increases, the level of size difference in organizations also increases, thereby reducing the competitive tension within the population and, as a result, their inclination to compete with other populations.

We should not confuse the cross effects of concentration model with the resource partitioning model (Carroll, 1985). Carroll put forward the hypothesis that, as market concentration increases, mortality rates in specialist organizations decline and in generalist organizations they rise. The exogenous variable is not the level of concentration that exists in each organizational form (or cross effects of concentration), but it is the level in the market in general. Competition between organizational forms is not, therefore, the driving force of the resource partitioning model (Boone et al., 2000).

\subsection{Competition between organizational subforms}

As we have already mentioned, competition between populations arises when their fundamental niches overlap. Although there are diverse situations in which the niches of interacting populations do cross, in this paper we have concentrated on one particular case where the population is divided into two organizational subforms (Pólos et al., 2002).

Traditionally, organizational form is defined as a blueprint for organizational action, for transforming inputs into outputs (Hannan and Freeman, 1977, p. 935). The crucial assumption underlying the notion of organizational forms is that it is possible to identify relatively invariant organizational characteristics that make for stability over time, which commits the organization to a recognizable set of environmental dependencies and to a limited range of plausible behaviours (Freeman and Lomi, 1994, p. 273). However, this static assumption is actually overcome. Form would be a type of identity understood as a function of the social codes that specify the properties that an entity can legitimately possess (Pólos et al., 2002).

On the basis of this definition, population is conceived as a set of entities (organizations) with a common minimal external identity in a bounded system in a period of time (Pólos et al., 2002; Hannan et al., in press). However, in spite of insiders and outsiders that could fix the minimal identities that identify the organizational form, there are distinctions that would legitimate their analysis and permit the definition of the subform as a new unit of analysis (Pólos et al., 2002, pp. 23-24).

Inside any population, one of the important distinctive features that serve to define subforms is ownership structure (Aldrich and Marsden, 1988, p. 58; Meyer and Zucker, 1989, p. 71).

The structure of property rights defines the institutional basis of power relations among individuals in the production process within the organization, and in the exchange between organizations (Bowels, 1984). This structure affects the election process of organizational form (Robbins, 1987; Lazerson, 1988) and, therefore, organizational diversity. Likewise, the ownership structure affects firm performance by emphasizing how basic organizational design elements, such as incentives and monitoring, shape patterns of organizational learning (Sorenson and Sorensen, 2001).

Using the criterion of ownership structure, we can distinguish two organizational subforms: stock form and mutual form. This classification has been frequently used in ecological research (Barnett and Carroll, 1987; Ranger-Moore et al., 1991; Hannan and Carroll, 1992; Haveman, 1992; Rao and Neilsen, 1992; Barron et al., 1994, 1998).

These subforms differ from each other on several points. On the one hand, the underlying incentive is the possibility that owners must obtain profits from a profitable investment. In 
the mutual subform, the main incentive is the satisfaction of the common needs of its members and the feeling of solidarity. The main difference between a member of the mutual subform and the participants in the stock subform is the dichotomy arising from the double condition of supplier/owner or customer/owner in the same person, thereby conferring a considerable portion of power to him/her within the organization. In the stock subform, different people normally undertake each of the supplier, customer, and owner roles. In the stock subform separation between ownership and control normally exists. Nevertheless, in the mutual subform, integration between the participation in a project and its codirection supposes that a considerable effort of 'cooperative spirit' has to be undertaken by the members (Staber, 1992, p. 1193).

Another difference has to do with power structure and governance system. The stock subform is based on the direct relationship between management power and owned capital, the capital subscribers being those who, as owners, undertake the management of the enterprise (Bowels, 1984). In the mutual subform, the organizations are constituted as democratic organizations controlled by their members and run on the principle of one member, one vote, with the value of each vote being the same, irrespective of the financial investment made by the member of the organization (Barron et al., 1994). The members have full control, irrespective of the amount of capital invested, which only serves to accredit them as owners (Ingram and Simons, 2000).

The structure of those organizations integrated in the mutual subform is determined by the cooperative principles stated by the International Cooperative Alliance (1995), which, at the same time, constitute not only the spirit but also the characteristic features of the running of an organization of this type. These principles would constitute the organization's ideology, which plays a fundamental role in determining the organizational form (Simons and Ingram, 1997).

Another difference has to do with profit sharing. In the stock subform, capital, as a priority production factor, is paid irrespective of its contribution to the fulfilment of organizational goals; in the mutual subform, the idea is to reward the fulfilment of goals such as the creation of wealth and the creation of value added, which highlight the 'person' as a production factor as opposed to others (Jeantet, 2000).

Having proved the validity of the previous classification of organizational subforms, the next step is to investigate whether these forms compete. Beforehand, it was convenient to underline some of the elements that allow us to speculate about some of the possible links between the organizational subforms indicated. However, none of these speculations allows us to develop formal hypotheses, which is consistent with other papers that have examined competition between populations but have not explicitly established hypotheses (Carroll and Wade, 1991; RangerMoore et al., 1991; Carroll and Swaminathan, 1992; Staber, 1992; Barron et al., 1998; Lomi, 1995, 2000).

Populations are divided into segments that react heterogeneously to competitive and institutional processes (Lomi, 1995). This conclusion is consistent with the idea that it is difficult to conceive of populations in a perfectly linked graph in which each organization affects and is affected by another (Lomi, 1995; Baum and Haveman, 1997). In our case, the two organizational subforms depend on similar sets of resources, with the absence of institutional or technological boundaries that could provoke further divisions. The high degree of overlapping of their niches is what gives rise to competition between both organizational subforms (Baum and Singh, 1994; Ingram and Baum, 1997; Barron et al., 1998; Hannan et al., in press).

In principle, one would suppose the mutual subform to be less competition oriented than the stock subform, because of the values and principles that determine the way it is run. Nevertheless, the idea of a common cooperative culture and tradition, as the basis for cooperative and mutualist relations, stands in contrast to the observation that cooperatives sometimes behave as 'mini-capitalists' (Bradley and Gelb, 1983), competing with other organizations not only for material resources but also for political support and social legitimacy (Staber, 1992). Some case studies suggest that, especially in competitive environments, mutuals, rather than stock subform firms, are often pressured into adopting procedures that are more efficient and, in this 
way, obtain competitive advantages (Staber, 1992, p. 1194). These arguments lead us to believe that both subforms should compete to obtain the resources they need to survive.

To confirm this supposition, we will apply the models of competitive interactions mentioned in the previous section to the organizational subforms found in a specific industry, which will so allow us to test the validity of the new models.

\subsection{Organizational subforms in the olive oil production industry}

To test this theoretical background we will use the olive oil production industry in the province of Jaén. We chose this industry because the province is a leader in the production of olive oil, with an average annual production of $312,000 \mathrm{t}$, which constitutes $13.8 \%$ of world and $17.7 \%$ of European olive oil production (Consejo Oleicola Internacional, 2001).

By taking the oil mill form ('almazara') and examining the ownership structure of the firm, it is possible to distinguish the two organizational subforms described in the theoretical background. On one side, there are mutual oil mills that mill their members' olives; they generally belong to cooperatives. On the other, there are stock oil mills that comprise organizations belonging to private enterprises that either mill the olives acquired from farmers through diverse contracts or mill the olives from their own groves.

Therefore, both subforms operate in the same business, in the same customer market, but they differ in (1) the nature and motivation of those who constitute the organization, (2) the governance system, (3) profit sharing, (4) the support received from public administration, and (5) their taxation status (Barron et al., 1998, p. 16).

The competition between these subforms is established, theoretically, in two arenas: first, through the acquisition of raw materials (olives); and second, through the release of the final product (olive oil). However, in reality, competition is almost exclusively reduced to the first of these environments, given that the commercial incapacity of the oil mills, both mutuals and stock, means that the production of virgin olive oil obtained is sold at the price set by the companies at the next stage in the agro-alimentary chain, that is, by multinationals that operate in a pseudo-oligopoly (Parras-Rosa, 1997; TorresRuíz, 1998; Torres-Ruíz et al., 2000).

The rapid decomposition of the fruit after it is harvested means that the fruit must be transformed into oil immediately after harvest to avoid a reduction in quality and a consequential loss in market value (Uceda-Ojeda and HermosoFernández, 1997). This obliges the oil mills to locate their plants close to their suppliers, which explains the high number (or density) of organizations in this industry. In Figure 1, we show the evolution of the density of both organizational subforms mentioned over the period from 1944 to 1998 .

To understand this figure, we must indicate that the mutual subform appears after the stock subform (Hoogveld and Jurjus, 1990, p. 37). The development of the mutual subform in the olive

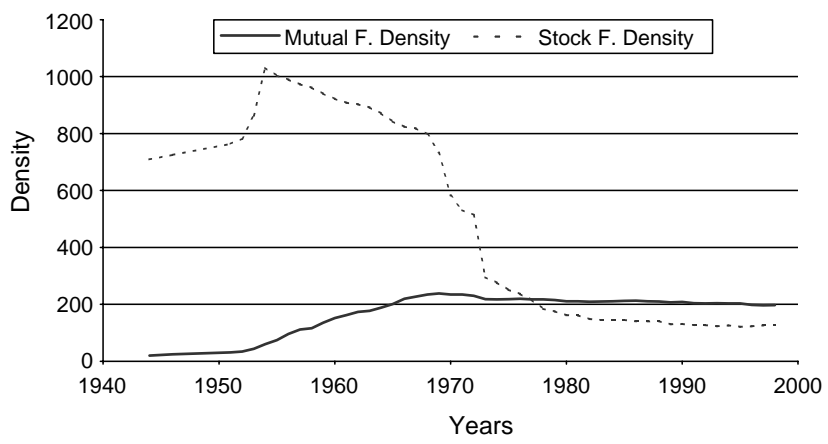

Figure 1. Number of mutual and stock olive oil mills during the period 1944-1998. 
oil sector is relatively recent and coincides with a characteristic period of history (1950-1970) in which the Spanish economy and agriculture lived in complete autarky (López-Ontiveros, 1982, p. 48). Moreover, public administration resolutely supported this organizational subform (López-Ontiveros, 1982). For this reason, up until 1977 the number of stock oil mills was far higher than the number of mutual oil mills (Figure 1), with 1954 being the year with the greatest difference in density (a difference of 971 oil mills). After 1977, an important qualitative change took place in the structure of this industry, which resulted in the mutual subform becoming the more important.

On the other hand, the loss of quality that the fruit undergoes from the moment it is delivered obliges the oil mill to install adequate milling capacity. The difficulty entailed in predicting the exact amount of fruit available in any particular harvest, and the need to guarantee its rapid transformation forces the oil mills to install productive capacities according to the maximum fruit delivery. To this, we must add the technological advances in extraction systems, which have increased milling capacities. Figure 2 shows the evolution of the aggregate size of each organizational subform (or population mass).

We can deduce that, although the mutual subform mass has not stopped growing through the study period, the stock subform mass has remained practically constant. We can prove that, as in the evolution of density, after the 1970s the mutual subform overtakes the stock subform in what is referred to as transformation of raw material potential. After the 1990s, both subforms increase in size as a result of the technological advances in the extraction systems.

To finalize the characterization of the organizational subforms that make up this industry, and considering the evolution in the number of participants and in the aggregate size of each of them, it is also necessary to observe the evolution of their levels of concentration. These levels appear in Figure 3, where the evolution, which is totally opposite in the concentration of both organizational subforms, is represented. Whereas in the mutual subform, concentration has declined to the point where it has remained constant, the stock subform remained constant until the 1970s, when it began to increase. That is, the increase in concentration in the stock subform is due to there being fewer, but larger, organizations, whereas the concentration of the mutual subform declined because, on the whole, it grew more in aggregate size than in the number of organizations. Nevertheless, we note that there was excessive fragmentation in both organizational subforms, although mainly in the stock subform, as is shown by the low Herfindhal index values during the period analysed.

\section{Method}

\subsection{Data sources and sample}

To develop this research we have built two databases that contain information on each of the organizational subforms found in the olive oil

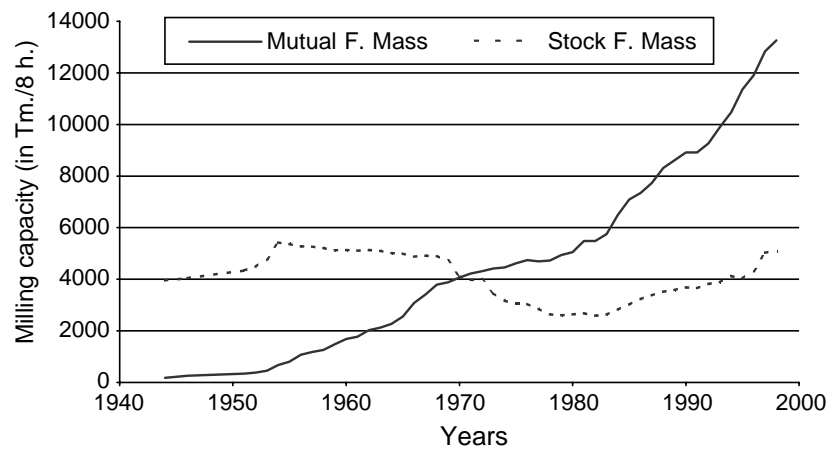

Figure 2. Aggregate size of the mutual and stock form during the period 1944-1998. 


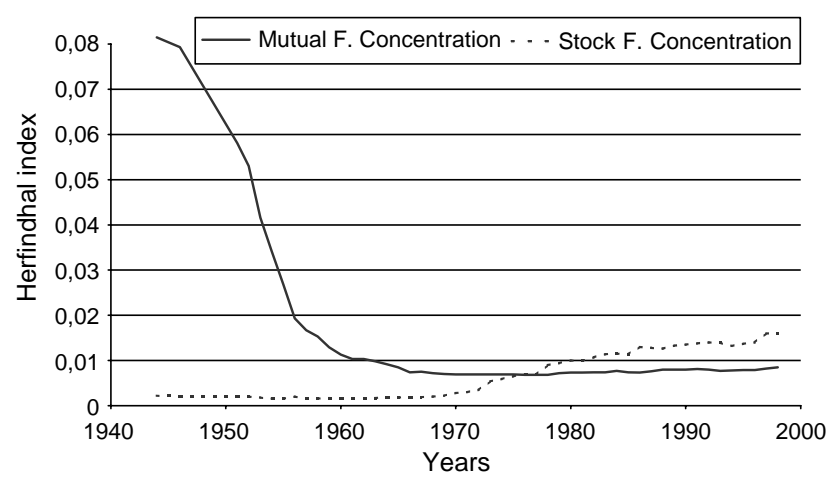

Figure 3. Concentration levels in the mutual and stock form during the period 1944-1998.

production industry in the province of Jaén for the period 1944-1998. The data was obtained from the Register of Agricultural Firms of the Agriculture and Fisheries Department, and from the Register of Cooperatives of the Trade and Industry Department of the Andalusian Regional Government.

The database that includes the stock subform comprises 716 oil mills that operated at some time during the study period. Of these oil mills, 392 disappeared during the study period, whereas data concerning the rest are censored (Lawless, 1982; Cox and Oakes, 1984). The second database comprised 303 mutual oil mills, of which 70 disappeared between 1944 and 1998.

The disappearance of an oil mill is considered to have occurred when it stopped operations, but not when its ownership or trade name changed, since, in these cases, there are no justifiable reasons to conclude that the whole organization has been transformed; in fact, it could continue using the same procedures and routines (Baum and Mezias, 1992; Ingram and Inman, 1996).

\subsection{Variables}

\subsubsection{Density}

We measure this variable as the number of active oil mills at the beginning of each year. We have introduced this variable into the model in a linear specification and in a quadratic specification with the result divided by 10 . The reason for having included this variable with its quadratic specification is to attempt to register non-linear effects between the exogenous variables and the probability of survivorship (Hannan and Carroll, 1992). We have calculated this variable for both the mutual and the stock subform.

\subsubsection{Population mass}

This variable takes into account the aggregate of the sizes of all the oil mills that were active at the beginning of each year. As with density, we have incorporated this variable into the models in a linear specification and in a quadratic specification with the result divided by 100 (Barnett and Amburgey, 1990). We have also calculated it for both the mutual and stock subforms.

\subsubsection{Concentration}

This variable takes into account size equality of the oil mills that make up the respective organizational forms. We measure it by using the Herfindhal index. We chose this index because (1) it verifies the properties required from the concentration indices (Hannah and Kay, 1977; Encauoua and Jacquemin, 1980), (2) it has already been used as a measure of concentration in ecological literature (Barnett and Carroll, 1987; Wholey et al., 1992), and (3) it is a suitable indicator of concentration, because it gives more importance to the disparity of sizes between organizations than to the number of organizations. We have introduced this variable into the models in a linear specification and in a quadratic specification with the result multiplied by 10,000 , and independently calculated for each subform as with density and mass. 


\subsection{Control variables}

The possible existence of effects provoked by variables other than exogenous variables has forced us to introduce two types of control variables. First, we developed the characteristics, peculiar to the organizations, that are not being studied in this paper but that may affect their failure. Next, we developed the variables that affect the probability of death and thus are the variables that characterize the environmental situation.

\subsubsection{Age periods}

We use six age-period dummy variables to control for age dependence in mortality (Ingram and Simons, 2000).

\subsubsection{Exploitation system}

Given that Boone, Bröcheler and Carroll (2000) discovered that whether production ownership fell on one or on various owners affects the probability of organizational failure, we created a dummy variable that tells us, at any moment, if the owner exploits the oil mill (value 1) or if it is exploited under lease (value 0 ).

\subsubsection{Organizational size}

We have identified the natural logarithm of milling capacity installed as a variable that represents the organizational size of each oil mill by following the stream of investigation within organizational ecology that regards organizational size as capacity (see Barron et al., 1994, p. 395). We could also consider that the installed production capacity is the best measure of size, given that it takes into account the space of the niche occupied by each organization (Winter, 1990). We log this variable to account for decreasing returns to scale (Sorenson and Sorensen, 2001, p. 719).

\subsubsection{Types of technology}

Technology influences on the performance of organizations, and signs of such influence are reflected in mortality rates (Barnett, 1990; Suárez and Utterback, 1995; Carroll and Teo, 1996). To control possible variations in the probability of failure according to the type of technology used, we introduced two dummy variables: obsolete technology and advanced technology. These variables take a value of 1 if the oil mill used either of the two types of technology, and 0 in the opposite case. We introduced both variables because both may exist simultaneously in the same organization, even though in different production lines.

We introduced the following environment control variables:

\subsubsection{Electric energy cost}

Electric energy is the power source that supplies the production system of an oil mill. This variable takes into account the cost of this supply in pesetas $/ \mathrm{kW}$ per hour, which we obtained from Bernal (1994) and the Ministerial Orders and Royal Decrees that annually set the price of electricity. This variable has been introduced by following the approaches observed in other studies that, by estimating vital rates, control the incidence of the main organization cost (Barnett and Carroll, 1987; Mascarenhas, 1996).

\subsubsection{Institutional endorsement}

Institutional theory proposes that increased embeddedness of a population in its institutional environment facilitates its growth and survival as time passes (Meyer and Rowan, 1977; Meyer and Scott, 1983). Ecologists agree that this connection increases a population's chances of survival and growth by improving the capacity of the population members to mobilize resources and increase their legitimation (Hannan and Carroll, 1992, p. 41). Several studies confirm that links with the institutional environment increase organizational survival chances (Singh et al., 1986; Miner et al., 1990; Baum and Oliver, 1991). Given that institutional endorsement could eliminate or reduce the limitations inherent in the environment, we have introduced a control variable that takes into account the years of governmental action implying endorsement of the constitution of organizations within the mutual subform. In the literature, such support has been represented by dummy variables associated with the approval received over a given period (Carroll and Hannan, 2000, pp. 203-204). For this reason, we have used a dummy variable that takes into account the period effect derived from institutional endorsement of the mutual subform, and it covers the period 1950-1970. 


\subsection{Analysis}

To carry out the necessary tests, we have used the piecewise-exponential model with the following hazard rate:

$$
r(t)=e^{\beta x(t)},
$$

where $\beta$ is the associated vector of coefficients and $X$ the matrix of exogenous and control variables. The values of the different variables were introduced in one-year spells. This model allows us to solve the left-truncated data problem by including the age periods as control variable, and using calendar time as a dependent variable that allows us to estimate the instantaneous probability of failure $r(t)$.

Following the methodology explained above, we used the statistical package Stata 6.0 (Stata Corporation, 1999) to estimate the $\beta$ parameters. If $\beta$ has a positive sign, the organization's probability of failure will increase, whereas, this probability will be reduced if the sign is negative.

\section{Results}

In Table I, we show the basic statistics and the correlations between exogenous and control variables for each organizational subform. Tables II and III show the different models of competition between populations stated in the theoretical background, for each of the organizational subforms analysed.

In Table II, we present four piecewise-exponential models of mortality in the stock subform. Model 1 takes into account the cross effects of density model, revealing the impact that the number of mutual and stock oil mills has on mortality rates in the stock subform. We can observe that the only significant exogenous variables are the quadratic specification of the cross effects of density and the linear effect of the stock subform, throwing into relief the evidence that the cross effects of density model fits this phenomenon, although with a fuzzier effect (less significance) when we analyse the influences of the stock subform density.

To give a graphic idea of the magnitude of the nonlinear effect of density of the stock and mutual subforms on mortality rates in the stock subform, we have calculated and graphically represented (Figures 4 and 5) the multipliers of the aforementioned densities. We can see how the risk of failure of the stock oil mills decreases slowly as the stock subform density increases. On the other hand, we can also see that the risk of failure of the stock oil mills increases at first slowly, but later rises sharply as mutual subform density increases.

In Model 2, we can see how only the mutual subform mass has a highly significant relation to mortality rates of stock oil mills with both the linear and quadratic coefficients (the former positively related and the latter negatively). That is, when the aggregate of the sizes of the mutual subform increases, competition between both forms intensifies, so augmenting the risk of failure in the stock subform up to a certain level, after which the probability of failure decreases (Figure 6).

Comparing both models, we can see the similarity between their global $\chi^{2}$ tests for the same degrees of freedom. There is only a difference of 0.69 in favour of the density cross effect. However, we can also see that the mass variable has higher significance levels for both coefficients.

In Model 3, we can observe the highly significant impact that mutual subform concentration has on stock subform mortality rates. Both the linear and the quadratic components of the cross effects of concentration are also significant. To identify the pattern that stock subform mortality rates follow in terms of the level of concentration of the mutual subform, we have calculated its multiplier. In Figure 7, we graphically reproduce the behaviour of this multiplier, observing that it follows a nonmonotonic $U$-shaped pattern, which means that the probability of failure in stock oil mills is reduced with mutual subform concentration until it reaches a certain level, after which the probability of failure of the stocks increases exponentially. However, contrary to former models, in this model there is also a clear and highly significant influence from the stock subform concentration on the probability of failure in the stock subform. In Figure 8, we graphically reproduce the behaviour of this multiplier, observing that it follows an inverse $U$-shaped pattern, which means that probability of failure in stock oil mills is increased with stock subform concentration until 


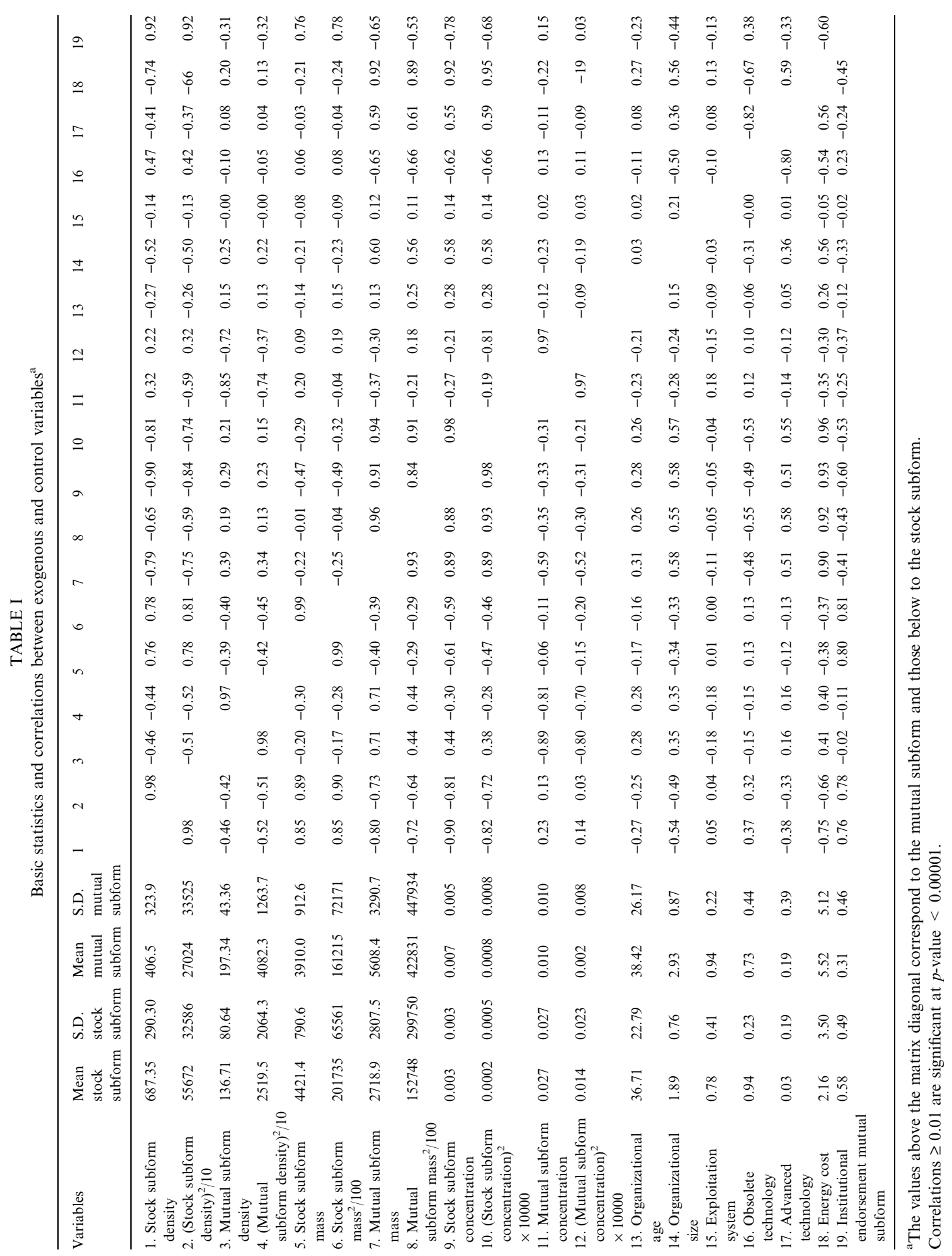


TABLE II

Piecewise-exponential models of mortality in stock subform, 1944-1998

\begin{tabular}{|c|c|c|c|c|}
\hline Variables & Model 1 & Model 2 & Model 3 & Model 4 \\
\hline \multicolumn{5}{|l|}{ Age periods } \\
\hline $0-10$ years & $0.057(0.078)$ & $0.062(0.079)$ & $0.055(0.081)$ & $0.094(0.079)$ \\
\hline $10-20$ years & $0.014(0.038)$ & $0.015(0.037)$ & $0.045(0.036)$ & $0.001(0.038)$ \\
\hline 20-30 years & $-0.020(0.299)$ & $-0.021(0.029)$ & $-0.035(0.029)$ & $-0.017(0.030)$ \\
\hline $30-40$ years & $0.035(0.027)$ & $0.034(0.027)$ & $0.036(0.028)$ & $0.037(0.027)$ \\
\hline $40-50$ years & $-0.011(0.022)$ & $-0.011(0.022)$ & $-0.006(0.022)$ & $-0.016(0.022)$ \\
\hline $50+$ years & $0.003(0.005)$ & $0.003(0.005)$ & $0.004(0.005)$ & $0.004(.005)$ \\
\hline Stock subform density & $-0.005^{*}(0.002)$ & & & $-0.010(0.008)$ \\
\hline (Stock subform density) $)^{2} / 10$ & $0.00001(0.00002)$ & & & $-0.00006(0.00006)$ \\
\hline Mutual subform density & $-0.019(0.010)$ & & & $-0.228^{* * * *}(0.053)$ \\
\hline (Mutual subform density) $^{2} / 10$ & $0.001^{* * * *}(0.0003)$ & & & $0.005^{* * * *}(0.001)$ \\
\hline Stock subform mass & & $0.0007(0.0007)$ & & $-0.005(0.003)$ \\
\hline (Stock subform mass) $^{2} / 100$ & & $-0.00001(0.00001)$ & & $0.0001 *(0.00004)$ \\
\hline Mutual subform mass & & $0.001 * * * *(0.0001)$ & & $0.001(0.001)$ \\
\hline (Mutual subform mass) $^{2} / 100$ & & $-5.2 \mathrm{E}-06^{* * * *}(9.8 \mathrm{E}-07)$ & & $-0.00001 *(5.4 \mathrm{E}-06)$ \\
\hline Stock subform concentration & & & $1181 * * * *(157.1)$ & $-262.83(551.44)$ \\
\hline $\begin{array}{l}\text { (Stock subform concentration })^{2} \\
\times 10,000\end{array}$ & & & $-9335^{* * * *}(1373.5)$ & $-1545.9(2570.3)$ \\
\hline Mutual subform concentration & & & $-246^{* * * *}(35.6)$ & $-579.01 * * * *(164.4)$ \\
\hline $\begin{array}{l}{\text { (Mutual subform concentration })^{2}} \times 10,000\end{array}$ & & & $239.32 * * * *(39.14)$ & $404.05 * * * *(114.83)$ \\
\hline Organizational size & $-1.08 * * * *(0.085)$ & $-1.10 * * * *(0.085)$ & $-1.06^{* * * *}(0.086)$ & $-1.10 * * * *(0.085)$ \\
\hline Exploitation system & $-0.046(0.111)$ & $-0.043(0.111)$ & $-0.046(0.111)$ & $-0.054 * * * *(0.085)$ \\
\hline Obsolete technology & $0.472(0.457)$ & $0.437(0.456)$ & $0.458(0.456)$ & $0.490(0.457)$ \\
\hline Advanced technology & $-1.56(0.849)$ & $-1.67^{*}(0.848)$ & $-1.55(0.849)$ & $-1.58(0.850)$ \\
\hline Energy cost & $-0.059 *(0.027)$ & $-0.301 * * * *(0.038)$ & $0.388 * * * *(0.085)$ & $0.113(0.123)$ \\
\hline $\begin{array}{l}\text { Institutional endorsement } \\
\text { of mutual subform }\end{array}$ & $0.784 * * *(0.239)$ & $0.886^{* * * *}(0.221)$ & $0.736^{* *}(2.68)$ & $1.19 * * * *(0.292)$ \\
\hline Constant & $-2.23 *(1.13)$ & $-6.9 * * * *(1.63)$ & $-4.48 * * * *(1.09)$ & $33.67 * * * *(9.05)$ \\
\hline Chi-squared $\left(\chi^{2}\right)$ & $803.90 * * * *$ & $803.21 * * * *$ & $716.14^{* * * *}$ & $858.8^{* * * *}$ \\
\hline Df & 16 & 16 & 16 & 24 \\
\hline
\end{tabular}

${ }^{\text {a }}$ Standard errors are in parentheses.

$* * * * p<0.0001 ; * * * p<0.001 ; * * p<0.01 ; * p<0.05$.

it reaches a certain level, after which the probability of failure of the stocks decreases.

Comparing this model with the previous one, we can conclude that the cross effects of concentration model presents a similar complex pattern of competition between both subforms (nonmonotonic pattern), although, in the opposite sense. Despite this, the cross effects of concentration model is the least accurate predictor of the influence of competition between populations on the probability of failure, since, its $\chi^{2}$ test is smaller (87.07).

Table II also shows Model 4, where all independent variables are included together (density, mass, and concentration). In this model, we can see how most of the variables change their signif- icance level. For instance, Stock subform density, Mutual subform mass, Stock subform concentration and (Stock subform concentration) ${ }^{2}$ lose all their degrees of significance. In contrast, Mutual subform density and (Stock subform mass) ${ }^{2}$ obtain significance in this model despite being non-significant in former models. Perhaps the high correlation between all these independent variables (multicolinearity) is the reason for these changes (Table I).

In Table II, the significant repercussions that the organizational control variables have on stock mill failure probability can be detected. More specifically, in all three models we can see how the $\log$ (size) of a stock oil mill has a highly significant negative impact on its probability of 
TABLE III

Piecewise-exponential models of mortality in mutual subform, 1944-1998

\begin{tabular}{|c|c|c|c|c|}
\hline Variables & Model 5 & Model 6 & Model 7 & Model 8 \\
\hline Age periods $0-10$ years & $0.153(0.289)$ & $0.156(0.290)$ & $0.161(0.289)$ & $0.150(0.286)$ \\
\hline $10-20$ years & $0.152(0.105)$ & $0.154(0.104)$ & $0.159(0.103)$ & $0.159(0.104)$ \\
\hline $20-30$ years & $-0.136(0.083)$ & $-0.139(0.082)$ & $-0.139(0.083)$ & $-0.137(0.083)$ \\
\hline $30-40$ years & $0.085(0.084)$ & $0.091(0.084)$ & $0.098(0.085)$ & $0.084(0.085)$ \\
\hline $40-50$ years & $0.060(0.059)$ & $0.054(0.059)$ & $0.047(0.060)$ & $0.056(0.060)$ \\
\hline $50+$ years & $-0.004(0.012)$ & $-0.003(0.012)$ & $-0.002(0.012)$ & $-0.003(0.012)$ \\
\hline Mutual subform density & $-0.037(0.027)$ & & & $-0.127(0.151)$ \\
\hline (Mutual subform density) $^{2} / 10$ & $0.001(0.001)$ & & & $0.004(0.003)$ \\
\hline Stock subform density & $-0.002(0.005)$ & & & $0.007(0.019)$ \\
\hline$(\text { Stock subform density) })^{2} / 10$ & $0.00001(0.0005)$ & & & $0.00003(0.0001)$ \\
\hline Mutual subform mass & & $0.0004(0.0003)$ & & $-0.0003(0.002)$ \\
\hline (Mutual subform mass) $^{2} / 100$ & & $-1.10 \mathrm{E}-06(2.2 \mathrm{E}-06)$ & & $5.36 \mathrm{E}-06(9.81 \mathrm{E}-06)$ \\
\hline Stock subform mass & & $0.001(0.001)$ & & $0.004(0.006)$ \\
\hline$(\text { Stock subform mass })^{2} / 100$ & & $-0.00003(0.00002)$ & & $-0.00008(0.00009)$ \\
\hline Mutual subform concentration & & & $-63.26(87.14)$ & $-104.86(546.82)$ \\
\hline (Mutual subform concentration) $)^{2} \times 10,000$ & & & $52.72(111.65)$ & $-53.13(480.62)$ \\
\hline Stock subform concentration & & & $585.68 *(292.1)$ & $1674.4(1328.5)$ \\
\hline$(\text { Stock subform concentration) })^{2} \times 10,000$ & & & $-5043.6^{*}(2138.1)$ & $-8874.8(5883.6)$ \\
\hline Organizational size & $-1.28 * * * *(0.211)$ & $-1.28 * * * *(0.211)$ & $-1.25 * * * *(0.211)$ & $-1.31 * * * *(0.214)$ \\
\hline Exploitation system & $-1.13^{* * * *}(0.309)$ & $-1.13 * * * *(0.308)$ & $-1.13 * * * *(0.306)$ & $-1.10^{* * * *}(0.308)$ \\
\hline Obsolete technology & $0.174(0.757)$ & $0.168(0.758)$ & $0.206(0.756)$ & $0.167(0.759)$ \\
\hline Advanced technology & $-0.890(0.843)$ & $-0.892(0.844)$ & $-0.888(0.842)$ & $-0.935(0.843)$ \\
\hline Energy cost & $0.139 * *(0.049)$ & $-0.003(0.075)$ & $0.387 * *(0.122)$ & $0.185(0.271)$ \\
\hline $\begin{array}{l}\text { Institutional endorsement } \\
\text { of mutual subform }\end{array}$ & $0.328(0.754)$ & $1.03(0.682)$ & $0.304(0.723)$ & $0.291(0.789)$ \\
\hline Constant & $-2.78(3.49)$ & $-8.01(4.18)$ & $-5.55(3.09)$ & $-10.30(25.29)$ \\
\hline Chi-squared $\left(\chi^{2}\right)$ & $126.03^{* * * *}$ & $124.25 * * * *$ & $123.09 * * * *$ & $137.6^{* * * *}$ \\
\hline Df & 16 & 16 & 16 & 24 \\
\hline
\end{tabular}

${ }^{\text {a }}$ Standard errors are in parentheses.

$* * * * p<0.0001 ; * * * p<0.001 ; * * p<0.01 ; * p<0.05$.

death. These results are consistent with those obtained in previous research that demonstrates that size is a variable that decreases the probability of organizational death (Carroll and Hannan,
2000). Another organizational variable that generates a significant negative impact is the type of technology used in the transformation phase. Oil mills that use the most advanced technology in

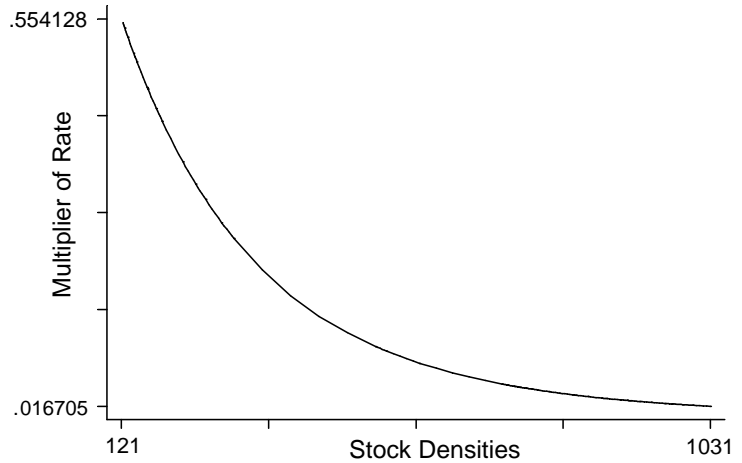

Figure 4. Effects of density impact on organizational failure probability of stock subform. 


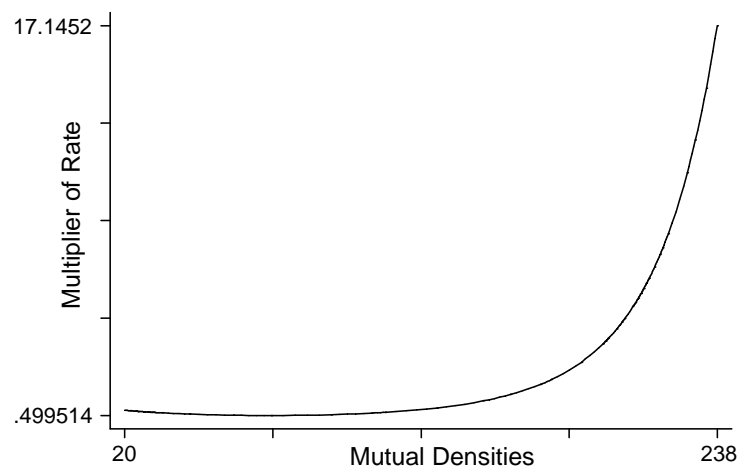

Figure 5. Cross effects of density impact on organizational failure probability of stock subform.

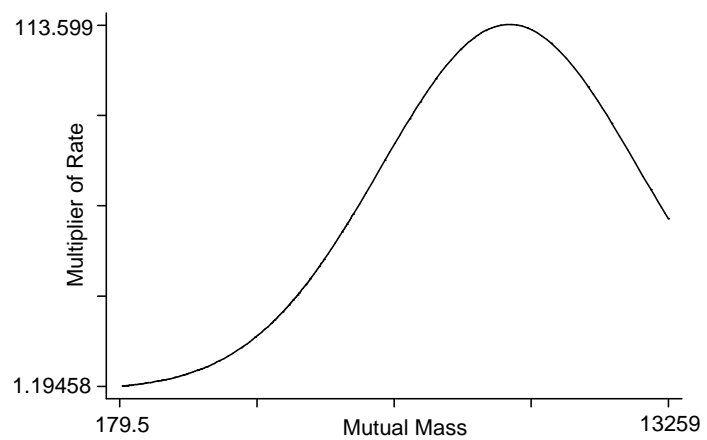

Figure 6. Cross effects of mass impact on organizational failure probability of stock subform.

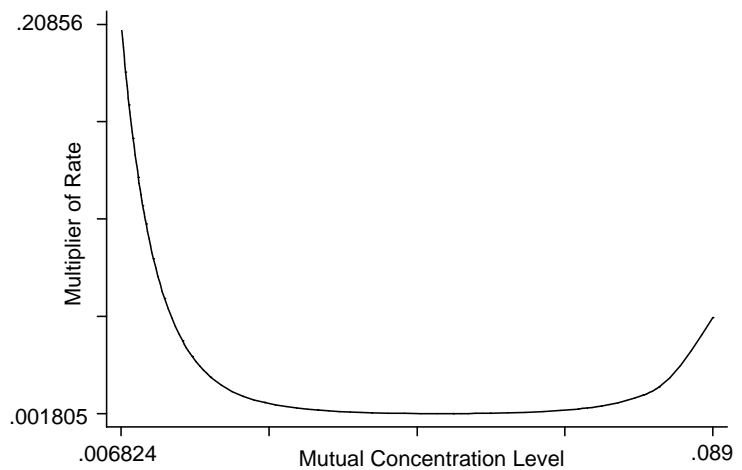

Figure 7. Cross effects of concentration impact on organizational failure probability of stock subform.

their production system run lower risks of failure. This is because the use of such technology reduces extraction costs, and produces more final product (Hermoso-Fernández et al., 1994).
With reference to the impact of the environmental control variables, we can see firstly that institutional endorsement received by the mutual subform has a positive influence on the probabil- 


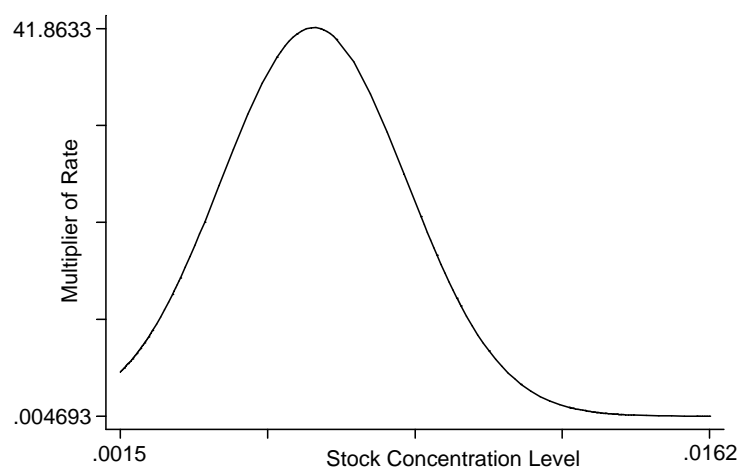

Figure 8. Effects of concentration impact on organizational failure probability of stock subform.

ity of failure of stock oil mills. Institutional endorsement of the mutual subform encouraged the constitution of this type of oil mill, and so had a negative impact on the continuity of the existing stock oil mills. Second, there is a contradictory relationship between the energy cost and the probability of failure, which is shown by the opposite signs of this variable in the first two models and in the third model.

In Table III, we present models of mutual subform mortality. Models 5 and 6 take into account models of competitive interactions using the absolute size (density or mass) of the stock subform. In both cases, we can see how the size of the stock subform does not have a significant influence on mutual oil mill mortality rates. The lack of significance in the cross effects of density and mass models could be caused by a certain degree of multicolinearity between the exogenous variables in linear terms and in their quadratic specification. Nevertheless, in order to maintain the same criteria as in the previous analysis, and given that the goodness of fit of the models did not substantially improve after the elimination of the quadratic specification, we opted to keep the most complete models.

In the Model 7 in Table III, we observe that the only variable that has a clear significance is the cross effects of concentration, both the linear and quadratic transformations. In order to detect more specifically how the risk of failure evolves as stock subform concentration increases, we must use the calculation of its multiplier and its graphical representation (Figure 9). In this graph, we can see an inverse $U$-shaped pattern.

In relation to the control variables used, we see, on the one hand, how the size of the oil mill is inversely related to the risk of failure, and, on the other hand, how the exploitation by the owner reduces the probability of death, which is derived from the specific nature of the mutual subform.

Finally, as with the stock subform, we have included all independent variables in an single model (Model 8). Again, we can see how all variables, without exception, lose their degree of significance.

\section{Discussion and conclusion}

This paper represents an effort to put forward new measures of the competition concept. Fundamentally, organizational ecology has concentrated on understanding competition as the fight between members of a population to obtain the resources they need, and analysing how such competition affects foundation, mortality, and organizational growth rates. The concept of competition is extended in this research by examining not only competition within a subform, as in the terminology of Pólos et al. (2002), but also competition from another subform that has similar resource needs. Our results show how, on some occasions, the competition for resources does not proceed from the members that constitute the subform, but from organizations integrated in a different subform. 


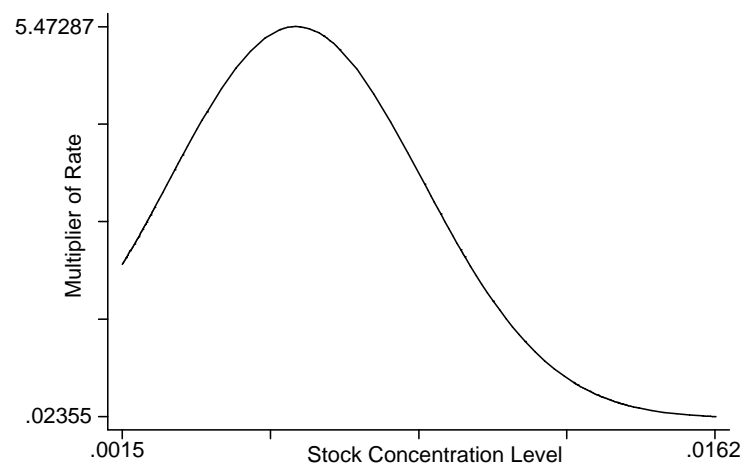

Figure 9. Cross effects of concentration impact on organizational failure probability of mutual subform.

From a methodological point of view, organizational ecology assumes that competition between populations is principally a function of density or of the number of organizations in competing populations. In this paper, we have modelled competition between organizational subforms by using density as well as other representative variables of a subform's competitive potential. Thus, we have considered, independently, that the threat of competition in a population depends on both the aggregate size of its members and the size distribution of each population or level of concentration.

The results indicate the usefulness of modelling competition between populations using these last two approaches. Moreover, our results suggest that employing usefulness analysis could be worthwhile (Farh et al., 1990; Pearce and Sims, 2002).

Of the three competitive interaction models, the concentration model is the only one that allows us to detect the impact of one subform on the other in each of the organizational subforms. More specifically, in the mutual subform, this model allows us to understand the type of influence that the stock subform has on the survival chances of mutual organizations. In this case, the cross effects of density model and the cross effects of mass model do not have sufficient capacity to reveal the influence of one subform on the other. These two models analyse competition in a superficial way because they do not examine thoroughly the power relationships produced between the members of the organizational subform, which would confirm the usefulness of designing the cross effects of concentration model. That is, it is possible to see how and in what way concentration has a bearing on the probability of failure. However, this model is less effective in explaining this probability of failure. Thus, it is possible that concentration is a measure of a dimension other than the concept of competition. Perhaps it is a concept of competition related to the degree of similarity between enterprises. A hypothetical case could arise in which all the organizations of a population are clonal, with their weighting in the niche having very little relevance. In this case, the cross effects of density model would coincide with the cross effects of mass model, given that the latter measurement would be a multiple of the former. In contrast, if there is a large degree of difference between organizations, the cross effects of density and the cross effects of mass models measure different things.

Applying the competitive interaction models, we can determine two basic questions that affect the success and survivorship of organizations in each subform. On one side, we detect the existence of interdependence between the organizational subforms that constitute the industry under analysis, and, on the other, it appears that the mutual subform is ecologically the stronger, as indicated by the significant impact produced by the cross coefficients. In any case, the complex relationship between the ownership structure and the competitive processes between the organizational subforms described becomes evident only in the case of the concentration effect. 
We conclude that we should incorporate the size of organization in the measurements used to model competition between populations, either by summing organizational sizes or through the level of concentration of the rival population. Moreover, the models developed using these measurements form a common link between researchers in the field of industrial organization and organizational ecology (Boone and van Witteloostuijn, 1995).

The validity of these results is conditioned by the development of similar studies in different environmental contexts, and in populations of other industrial sectors and services. The competitive interaction models designed in this research would be validated by statistically significant results. On the other hand, the significance given to the size of organization by the cross effects of mass and concentration models could have its disadvantages, as there is no direct evidence of causal mechanisms associated with the size of organization (Barron, 1999). Size is correlated to many other organizational characteristics and, for that reason, we must be cautious in using this variable as an explanatory causal factor of mortality.

Despite these limitations, the results allow us to point out some leads in this research to be followed up in the future. On the one hand, we could apply the competitive interaction models in the third level of analysis of ecological theory, community ecology, to observe the evolution of population communities. More specifically, and within the sector in question, we could examine how populations found at different stages of the olive oil agro-alimentary chain interact. For example, one might analyse what influence the populations of refining and bottling enterprises have on oil mill populations. On the other hand, one might analyse the behaviour of the cross effects of mass and the cross effects of concentration models in the area of organizational founding. It would also be useful to examine the prediction potential of the cross effects of concentration model when organizational growth rates are estimated.

Finally, this research has placed the spotlight on competition between populations as a potentially important factor in explaining the vital ratios. Clearly, competition between populations deserves more theoretical and empirical attention.

\section{Acknowlegements}

Investigation funded by SEC2001-0657 and FEGA-FEOGA (CA099-019). We would like to thank the anonymous referee for his or her insightful comments on an earlier version of this paper.

\section{References}

Aldrich, H. E. and E. R. Auster, 1986, 'Even Dwarfs Started Small: Liabilities of Size and Age and their Strategic Implications', in B. M. Staw and L. L. Cummings (eds.), Research in Organizational Behavior, Greenwich: JAI Press, pp. 165-198.

Aldrich, H. E. and P. V. Marsden, 1988, 'Environments and Organizations', in N. I. Smelzer (ed.), Handbook of Sociology, Beverly Hills: Sage, pp. 361-392.

Astley, W. G., 1985, 'The Two Ecologies: Population and Community Perspectives on Organizational Evolution', Administrative Science Quarterly 30, 224-241.

Barnett, W. P., 1990, 'The Organizational Ecology of a Technological System', Administrative Science Quarterly 35, 31-60.

Barnett, W. P., 1997, 'The Dynamics of Competitive Intensity', Administrative Science Quarterly 42, 128-160.

Barnett, W. P. and T. L. Amburgey, 1990, 'Do Larger Organizations Generate Stronger Competition?', in J. V. Singh (ed.), Organizational Evolution: New Directions, Newbury Park: Sage, pp. 78-103.

Barnett, W. P. and G. R. Carroll, 1987, 'Competition and Mutualism Among Early Telephone Companies', Administrative Science Quarterly 32, 400-421.

Barron, D. N., 1999, 'The Structuring of Organizational Populations', American Sociological Review 64, 421-445.

Barron, D. N., E. West and M. T. Hannan, 1994, 'A Time to Grow and a Time to Die: Growth and Mortality of Credit Unions in New York, 1914-1990', American Journal of Sociology 100, 381-421.

Barron, D. N., E. West, and M. T. Hannan, 1998, 'Deregulation and Competition in the Financial Industry', Industrial and Corporate Change 7, 1-32.

Baum, J. A. C. and H. A. Haveman, 1997, 'Love Thy Neighbor? Differentiation and Agglomeration in the Manhattan Hotel Industry, 1898-1990', Administrative Science Quarterly 42, 304-338.

Baum, J. A. C., H. J. Korn and S. Kotha, 1995, 'Dominant Designs and Population Dynamics in Telecommunications Services: Founding and Failure of Facsimile Transmission Service Organizations, 1965-1992', Social Science Research 24, 97-135.

Baum, J. A. C. and S. Mezias, 1992, 'Localized Competition and Organizational Failure in the Manhattan Hotel Industry, 1898-1990', Administrative Science Quarterly 37, 580-604.

Baum, J. A. C. and C. Oliver, 1991, 'Institutional Linkages and Organizational Mortality', Administrative Science Quarterly 36, 187-218. 
Baum, J. A. C. and J. V. Singh, 1994, 'Organizational Niches and the Dynamics of Organizational Mortality', American Journal of Sociology 100, 346-380.

Bernal, A. M., 1994, 'Balance de Resultados (1894-1992)', in J. Alcaide, A. M. Bernal, E. García-Denterría, J. Mª Martínez-Val, A. De Miguel, G. Núñez and J. Tusell (eds.), Compañia Sevillana de Electricidad: 100 Años de Historia, Sevilla: Fundación de la Compañía Sevillana de Electricidad, pp. 369-388.

Boone, C., V. Bröcheler, and G. R. Carroll, 2000, 'Custom Service: Application and Tests of Resource-partitioning Theory Among Dutch Auditing Firms from 1896 to 1992', Organization Studies 21, 355-381.

Boone, C. and A. Witteloostuijn, 1995, 'Industrial Organization and Organizational Ecology: The Potentials for Cross-fertilization', Organization Studies 16, 265298.

Bowels, R., 1984, 'Property Rights and the Legal System', in D. E. Whynes (ed.), What is Political Economy: Eight Perspectives, New York: Basil Blackwell, pp. 187-208.

Bradley, K. and A. Gelb, 1983, Worker Capitalism, Cambridge: MIT Press.

Brittain, J. W., 1994, 'Density-independent Selection and Community Evolution', in J. A. C. Baum and J. V. Singh (eds.), Evolutionary Dynamics of Organizations, New York: Oxford University Press, pp. 355-378.

Carroll, G. R., 1985, 'Concentration and Specialization: Dynamics of Niche Width in Populations of Organizations', American Journal of Sociology 90, 1263-1283.

Carroll, G. R. and M. T. Hannan, 1995, Organizations in Industry: Strategy, Structure and Selection, New York: Oxford University Press.

Carroll, G. R. and M. T. Hannan, 2000, The Demography of Corporations and Industries, New Jersey: Princeton University Press.

Carroll, G. R. and J. R. Harrison, 1994, 'The Historical Efficiency of Competition Between Organizational Populations', American Journal of Sociology 100, 720-749.

Carroll, G. R. and A. Swaminathan, 1992, 'The Organizational Ecology of Strategic Groups in the American Brewing Industry from 1975 to 1990', Industrial and Corporate Change 1, 65-97.

Carroll, G. R. and A. C. Y. Teo, 1996, 'Creative Selfdestruction Among Organizations: An Empirical Study of Technical Innovation and Organizational Failure in the American Automobile Industry, 1885-1982', Industrial and Corporate Change 6, 619-644.

Carroll, G. R. and J. Wade, 1991, 'Density Dependence in the Organizational Evolution of the American Brewing Industry Across Different Levels', Social Science Research 20, 271-302.

Consejo Oleícola Internacional, 2001, Proyección de la Producción y del Consumo de Aceite de Oliva en el Horizonte 2008, Madrid: Consejo Oleícola Internacional.

Cox, D. R. and D. Oakes, 1984, Analysis of Survival Data (Monographs on Statistics and Applied Probability), New York: Chapman and Hall.

Edwards, C. D., 1955, 'Conglomerate Bigness as a Source of Power', in National Bureau of Economics Research,
Business Concentration and Public Power, Princeton: Princeton University Press, pp. 331-359.

Encauoua, D. and A. Jacquemin, 1980, 'Degree of Monopoly, Indices of Concentration and Threat of Entry', International Economic Review 21, 87-105.

Farh, J. -L., P. M. Podsakoff and D. W. Organ, 1990, 'Accounting for Organizational Citizenship Behavior: Leader Fairness and Task Scope Versus Satisfaction', Journal of Management 16, 705-721.

Freeman, J. and M. T. Hannan, 1983, 'Niche Width and the Dynamics of Organizational Populations', American Journal of Sociology 88, 1116-1145.

Gause, G. F., 1934, The Struggle for Existence, Baltimore: Williams and Wilkins.

Hannah, L. and J. A. Kay, 1977, Concentration in Modern Industry: Theory, Measurement and the UK Experience, London: McMillan.

Hannan, M. T., 1986, 'Competitive and Institutional Processes in Organizational Ecology', Technical Report 86-13, Cornell: Department of Sociology, Cornell University.

Hannan, M. T. and G. R. Carroll, 1992, Dynamics of Organizational Populations: Density, Legitimation and Competition, New York: Oxford University Press.

Hannan, M. T., G.R. Carroll and L. Pólos, "The organizational niche", Sociological Theory, forthcoming.

Hannan, M. T. and J. Freeman, 1977, 'The Population Ecology of Organizations', American Journal of Sociology 82, 929-964.

Hannan, M. T. and J. Freeman, 1988, 'The Ecology of Organizational Mortality: American Labor Unions, 1836-1985', American Journal of Sociology, 94, 25-52.

Hannan, M. T. and J. Freeman, 1989, Organizational Ecology, Cambridge: Harvard University Press.

Hannan, M. T., J. Ranger-Moore, and J. Banaszak-Holl, 1990, 'Competition and the Evolution of Organizational Size Distributions', in J. V. Singh (ed.), Organizational Evolution: New Directions, Newbury Park: Sage, pp. 246-268.

Haveman, H. A., 1992, 'Between a Rock and a Hard Place: Organizational Change and Performance Under Conditions of Fundamental Environmental Transformation', Administrative Science Quarterly 37, 48-75.

Haveman, H. A., 1993, 'Organizational Size and Change: Diversification in the Savings and Loan Industry After Deregulation', Administrative Science Quarterly 38, 20-50.

Hermoso-Fernández, M., J. González-Delgado, M. Uceda-Ojeda, A. García-Ortiz-Rodríguez, J. MoralesBernardino, L. Frías-Ruíz and A. Fernández-García, 1994, Elaboración de Aceites de Oliva de Calidad. Obtención Por el Sistema de dos Fases, Sevilla: Consejería de Agricultura y Pesca de la Junta de Andalucía.

Hoogveld, A. and A. Jurjus, 1990, Olive Oil in Spain: Strategies and Prospects, Nijmegen: Institute for Social and Behavioural Sciences.

Hunt, C. S. and H. E. Aldrich, 1998, 'The Second Ecology: Creation and Evolution of Organizational Communities', in B. M. Staw and L. L. Cummings (eds.), 
Research in Organizational Behavior, Greenwich: JAI Press, pp. 267-301.

Hutchinson, G. E., 1957, 'Concluding Remarks', Cold Spring Harbor Symposium on Qualitative Biology 22, 415-427.

Ingram, P. and J. A. C. Baum, 1997, 'Chain Affiliation and the Failure of Manhattan Hotels, 1898-1980', Administrative Science Quarterly, 42, 68-102.

Ingram, P. and C. Inman, 1996, 'Institutions, Intergroup, Competition, and the Evolution of Hotel Populations Around Niagara Falls', Administrative Science Quarterly 41, 629-658.

Ingram, P. and T. Simons, 2000, 'State Formation, Ideological Competition, and the Ecology of Israeli Workers' Cooperatives, 1920-1992', Administrative Science Quarterly 45, 25-53.

International Cooperative Alliance, 1995, 'Agenda and Reports, Summaries and Translations', Geneva XXXIst Congress, Manchester 1995.

Jeantet, T., 2000, La Economía Social Europea o la Tentación de la Democracia en Todas Las Cosas, Valencia: Ciriec-España.

Lawless, J. F., 1982, Statistical Models and Methods for Lifetime Data, New York: Wiley.

Lazerson, M. 1988, 'Small Firm Growth: An Outcome of Markets and Hierarchies', American Sociological Review 53, 330-432.

Levinthal, D. A., 1991, 'Random Walks and Organizational Mortality', Administrative Science Quarterly 36, $397-420$.

Lomi, A., 1995, 'The Population and Community Ecology or Organizational Founding: Italian Cooperative Banks, 1936-1989', European Sociological Review 11, 75-98.

Lomi, A., 2000, 'Density Dependence and Spatial Duality in Organizational Founding Rates: Danish Commercial Banks, 1846-1989', Organization Studies 21, 433-461.

López-Ontiveros, A., 1982, Las Cooperativas Olivareras Andaluzas: Una Realidad Problemática, Córdoba: Publicación del Monte de Piedad y Caja de Ahorros de Córdoba.

Mascarenhas, B. 1996, 'The Founding of Specialist Firms in a Global Fragmenting Industry', Journal of International Business Studies 27, 27-42.

Meyer, J. W. and B. Rowan, 1977, 'Institutionalized Organizations: Formal Structure as Myth and Ceremony', American Journal of Sociology 83, 340-363.

Meyer, J. W. and W. R. Scott, 1983, Organizational Environments: Ritual and Rationality, Beverly Hills: Sage.

Meyer, J. and L. G. Zucker, 1989, Permanently Failing Organizations, Newbury Park: Sage.

Miner, A. S., T. L. Amburgey and T. M. Stearns, 1990, 'Interorganizational Linkages and Populations Dynamics: Buffering and Transformational Shields', Administrative Science Quarterly 35, 689-713.

Parras-Rosa, M., 1997, 'La Cadena Agroalimentaria de los Aceites de Oliva: Una Síntesis', in M. Parras-Rosa (coord.), La Reforma de la OCM y el Futuro Del Oli- var, Jaén: Universidad de Jaén y Universidad Internacional de Andalucía, pp. 77-111.

Pearce, C. L. and H. P. Sims, 2002, 'Vertical vs. Shared Leadership as Predictors of the Effectiveness of Change Management Teams: An Examination of Aversive, Directive, Transactional, Transformational and Empowering Leader Behaviors', Group Dynamics: Theory Research, and Practice, 6.

Pfeffer, J. and G. R. Salanzik, 1978, The External Control of Organizations: A Resource Dependence Perspective, New York: Harper and Row.

Pólos, L., M. T. Hannan and G. R. Carroll, 2002, 'Foundations of a Theory of Social Forms', Industrial and Corporate Change 11, 85-115.

Ranger-Moore, J., J. Banaszak-Holl and M. T. Hannan, 1991, 'Density-dependent Dynamics in Regulated Industries: Founding Rates of Banks and Life Insurance Companies', Administrative Science Quarterly 36, 36-65.

Rao, H. and E. H. Neilsen, 1992, 'An Ecology of Agency Arrangements: Mortality of Savings and Loan Associations, 1960-1987', Administrative Science Quarterly 37, 448-470.

Robbins, J. A., 1987, 'Organizational Economics: Notes on the Use of Transaction-cost Theory in the Study of Organizations', Administrative Science Quarterly 32, 68-86.

Scherer, F. M. and D. Ross, 1990, Industrial Market Structure and Economic Performance, Boston: Houghton Mifflin.

Silverman, B. S., J. A. Nickerson and J. Freeman, 1997, 'Profitability, Transactional Alignment and Organizational Mortality in the U.S. Trucking Industry', Strategic Management Journal 18, 31-52.

Simons, T. and P. Ingram, 1997, 'Organization and Ideology: Kibbutzim and Hired Labor, 1951-1965', Administrative Science Quarterly 42, 784-813.

Singh, J. V., D. J. Tucker and R. J. House, 1986, 'Organizational Legitimacy and the Liability of Newness', Administrative Science Quarterly 31, 171-193.

Sorenson, O. and J. P. Sorensen, 2001, 'Finding the Right Mix: Franchising, Organizational Learning, and Chain Performance', Strategic Management Journal 22, 713724

Staber, U. H., 1992, 'Organizational Interdependence and Organizational Mortality in the Cooperative Sector: A Community Ecology Perspective', Human Relations 45, 1191-1212.

Stata Corporation, 1999, Stata Statistical Software: Release 6.0. College Station, TX, Texas: Stata Press.

Suárez, F. F. and J. M. Utterback, 1995, 'Dominant Designs and the Survival of Firms', Strategic Management Journal 16, 415-430.

Swaminathan, A. and G. Wiedenmayer, 1991, 'Does the Pattern of Density-Dependence in Organizational Mortality Rates Vary Across Levels of Analysis? Evidence from the German Brewing Industry', Social Science Research 20, 45-73. 
Thompson, J. D., 1967, Organizations in Action, New York: McGraw-Hill.

Torres-Ruíz, F. J., 1998, Las Cooperativas Jiennenses y la Comercialización de los Aceites de Oliva: Una Perspectiva Estratégica, Jaén: Instituto de Estudios Giennenses.

Torres-Ruíz, F. J., O. Senise-Barrio, A. Mozas-Moral, M. Parras-Rosa and Eva Murgado-Armenteros, 2000, La Comercialización de los Aceites de Oliva en Andalucia: La Situación de las Cooperativas, Málaga: Unicaja.

Uceda-Ojeda, M. and M. Hermoso-Fernández, 1997, 'La Calidad del Aceite de Oliva', in R. Fernández and
L. Rallo (eds.), El Cultivo Del Olivo, Madrid: Junta de Andalucía y Mundi-Prensa, pp. 539-564.

Wholey, D. R., J. B. Christianson and S. M. Sanchez, 1992, 'Organizational Size and Failure Among Health Maintenance Organizations', American Sociological Review 57, 829-842.

Winter, S. G.,1990, 'Survival, Selection, and Inheritance in Evolutionary Theories of Organizations', in J. V. Singh (ed.), Organizational Evolution: New Directions, Newbury Park: Sage, pp. 269-297. 